\title{
Synchisis scintillans or Cholesterolosis bulbi of the anterior chamber in an infant patient
}

\author{
Sínquise cintilante ou colesterolosis bulbi \\ de câmara anterior em paciente lactente
}

Michelle Rodrigues Gonçalves Dias Chaves ${ }^{1}$; Isabella Bezerra Wanderley de Queiroga ${ }^{1}$; Mario Augusto Pereira Dias Chaves'; Edivânia Pereira Leite1; Débora Pires Sá de Oliveira

\begin{abstract}
The propose of this article is presenting a case report of Synchisis scintillans of the anterior chamber in an infant patient without any elucidation. The patient's initial complaint was "strabismus since birth". There was not found any other personal or family abnormalities. On examination: OS: Esotropia maintained, horizontal nystagmus, microphthalmia and leukocoria. OD: no abnormalities. Ultrasonography (USG) OS: reduction of the axial length, retinal applied and hyperechoic vitreous. Raised hypotheses were persistence of hyperplastic primary vitreous, congenital cataract and retinoblastoma, and there was also requested cranial and orbital cavity tomography (TC). The patient returned after six months with TC showing as sole evidenced hyperattenuating areas without signs of calcification on OS. On examination: OD showing direct pupillary reflex positive and consensual pupillary reflex negative. OS: conjunctival hyperemia and analysis of pupillary reflex frustrated by the presence of sparkling colored ocher in the anterior chamber. We asked for a new USG, which showed: punctate echoes in the vitreous cavity, suggesting hemorrhage; thickening of the posterior hyaloids; choroid and retina were attached, both with increased thickness. The synchisis scintillans or "colesterolosis bulbi" is a degenerative process commonly secondary to trauma, inflammation or intraocular hemorrhage. Evolves with deposition of cholesterol crystals (from degeneration of the lens or vitreous itself) in the vitreous cavity, subretinal space and rarely, in the anterior chamber. There are evidences that the phenomenon could arise from severe trauma, long-term cataract, hyphema, glaucoma or retinal detachment and, even more rarely, uveitis, neoplasias or vascular disorders. Until this case, there was no report of Synchisis scintillans in the anterior chamber involving an infant.
\end{abstract}

Keywords: Crystalization; Cholesterol/metabolism; Anterior chamber/pathology; Eye diseases/pathology; Infant; Case reports

\section{Resumo}

Este trabalho tem por objetivo relatar um caso de Sínquise cintilante de câmara anterior em lactente sem causa elucidada. O paciente apresentou desvio no olhar desde o nascimento. Antecedentes pessoais e familiares sem anormalidades. Ao exame: OE: Esotropia constante, nistagmo horizontal, leucocoria e microftalmia. OD: sem anormalidades. Ultrassonografia (USG) OE: redução do comprimento axial, retina aplicada e vítreo hiperecogênico. Aventaram-se hipóteses de persistência de vítreo primário hiperplásico, catarata congênita e retinoblastoma, e solicitou-se tomografia de crânio e cavidade orbitaria (TC). Paciente retornou após 6 meses, trazendo TC cuja única alteração evidenciada era OE com áreas hiperatenuantes e sem sinais de calcificação. Ao exame: OD: Reflexo pupilar direto positivo e consensual negativo. OE: hiperemia conjuntival, análise de reflexo pupilar inviabilizada por presença de sínquises cintilantes de coloração ocre na câmara anterior que não estava presente no exame inicial. Solicitou-se nova USG, evidenciando: ecos puntiforme na cavidade vítrea, sugerindo hemorragia, espessamento de hialóide posterior, retina aplicada e coróide com espessura aumentada. A sínquise cintilante ou "colesterolosis bulbi" é um processo degenerativo comumente secundário a trauma, inflamação ou hemorragia intraocular. Cursa com deposição de cristais de colesterol (provenientes do cristalino em degeneração ou do próprio vítreo) na cavidade vítrea, espaço sub-retiniano e, mais raramente, na câmara anterior. Sugere-se que o fenômeno decorra de traumas, catarata de longa duração, hifema, glaucoma secundário ou descolamento de retina e mais raramente, de uveítes, neoplasias ou vasculopatias. Até o presente, não há relato na literatura de sínquise cintilante de câmara anterior envolvendo um lactente.

Descritores: Cristalização; Coleterol/metabolism; Câmara anterior/patologia; Oftalmopatias/patologia; Lactente; Relatos de ca$\operatorname{sos}$

\footnotetext{
${ }^{1}$ Hospital Universitário Lauro Wanderley - Universidade Federal da Paraíba, João Pessoa, PB, Brazil.
}

The authors declare no conflicts of interest

Received for publication 09/07/2012 - Accepted for publication 24/02/2013

Rev Bras Oftalmol. 2015; 74 (5): 306-8 


\section{INTRODUCTION}

$\mathbf{S}$ ynchisis scintillans or cholesterolosis bulbi is a degenerative process characterized by the deposition of cholesterol crystals in vitreous cavity, subretinal space, and rarely in the anterior chamber. It is suggested that the phenomenon results from eye trauma, long-term cataract, recurrent intraocular inflammation or hemorrhage, hyphema, secondary glaucoma or retinal detachment and, more rarely, uveitis, neoplasia or vascular disorders ${ }^{(1)}$.

This study aims at reporting the case of an infant with colesterolosis bulbis or synchisis scintillans in the anterior chamber (SSAC) without elucidated cause, emphasizing the rarity of the case, and commenting on some assumptions about the etiology of these crystals and their location in anterior chamber.

\section{CASe RePort}

The initial complaint filed by the mother of the 1 year and a half infant was on the look deviation since birth. Personal and family history with no abnormalities. The exam showed: Inspection: RE: no change. LE: constant isotropy, horizontal nystagmus, leukocoria and microphthalmia (Figure 1). Indirect binocular ophthalmoscopy (IBO): RE: physiological relationship excavation / disc, characteristic macular brightness, vascular arcades of habitual compliance, applied retina. LE: not feasible. Ultrasonography (USG) LE: reduced axial length applied retina and hyperechoic vitreous.

Hypothesis of persistence of primary hyperplastic vitreous, congenital cataract and retinoblastoma emerged, and a $\mathrm{CT}$ scan of the brain and the orbital cavity was requested. The patient returned after six months with tearing and hyperemia in the LE and a TC demonstrating as the only change: LE with hyperattenuating areas and no signs of calcification. On examination: RE: pupillary reflection - direct positive and consensual negative. LE: conjunctival hyperemia, analysis of pupillary reflection frustrated by the presence of synchisis scintillans of ocher color in the anterior chamber (Figure 2) which was not present at the initial examination.

Fluormetolona $0.1 \%$ was prescribed in the LE, and a new USG was requested (Figure 3), indicating: punctate echoes in the vitreous cavity, suggesting bleeding, thickening of the posterior hyaloid, applied retina and choroid with increased thickness. Currently topical fluormetolona is still in use, and the infant evolves with a descrete reduction of conjunctival hyperemia.

\section{Discussion}

In the case presented, hypothesis of retinoblastoma or persistent primary vitreous, the first to be considered, seem unlikely before the results of complementary exams. Intrauterine infectious causes are not discarded. Further investigations involving a cytological study of the vitreous and the aqueous humor could bring relevant information to the case, but unfortunately they are still beyond the reach of most universities in our country.

The appearance of SSAC has been reported in the scientific literature since 1828 . However, there is a small number of descriptions due to the rarity of the event. Gruber ${ }^{(2)}$ reviewed all the literature on this subject, suggesting that if there is a rupture of the zonule, or a subluxation of the crystalline, there could be a passage of previously degenerated materials fron the vitreous or the crystalline to the anterior chamber through the pupil hole.

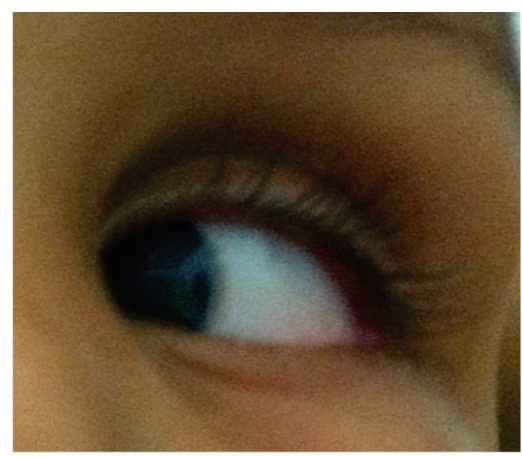

Figure 1: LE during initial inspection, showing constant isotropy, horizontal nystagmus, leukocoria and microphthalmia

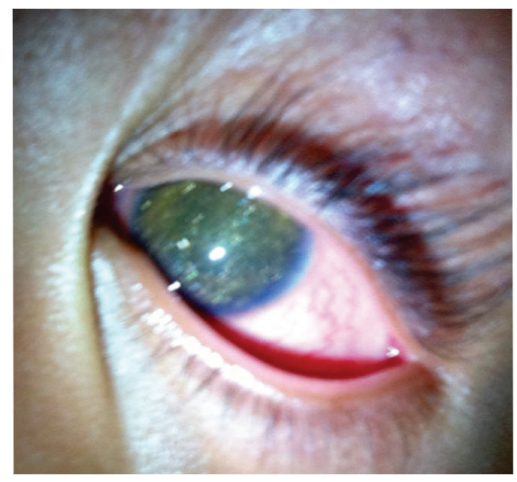

Figure 2: LE in a subsequent appointment, where conjunctival hyperemia is seen, and a pupillary reflection analysis is frustrated due to the presence of synchisis scintillans of ocher color in the anterior chamber

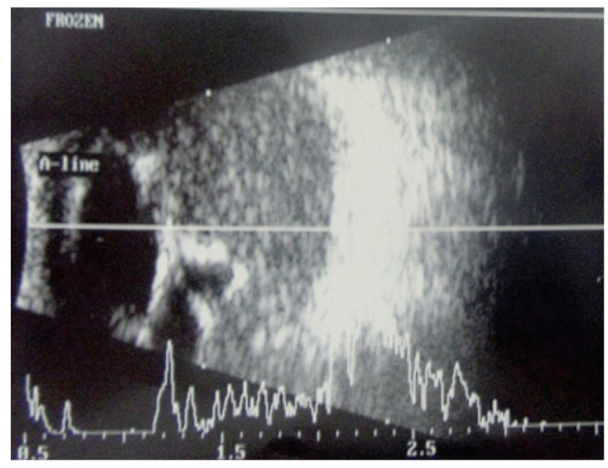

Figure 3: USG showing punctate echoes in the vitreous cavity, suggesting hemorrhage, posterior hyaloid thickening, applied retina and choroid with increased thickness

It is known that the normal crystalline is composed $63.5 \%$ of water and $36.5 \%$ of solids. The solids consist of proteins, inorganic salts of sodium, potassium, calcium, and lipids. Among the lipids are lecithin and cholesterol that increase their concentration with age. Cholesterol is also present in the vitreous, but in a lower concentration than in normal serum. Under pathological conditions, the blood / aqueous limit can be changed, allowing the entry into the vitreous of a larger amount of cholesterol. Free insoluble cholesterol condenses in the form of crystals. 
Andrews $^{(3)}$ says he has found significant cholesterol levels in the aqueous humor of normal eyes, suggesting the presence of a "carrier" protein responsible for the solubility of cholesterol in these eyes. Thus, it is possible that an interference with the normal blood flow to the anterior segment and a circulating cholesterol reflux to the aqueous humor exceed their capacity to keep cholesterol in a soluble state, thereby resulting in the condensation of the same and the formation of crystals. In the five cases presented in this paper, all in adults, the common findings were: the emergence of SSAC in eyes previously longtime traumatized with marked cataract and amaurosis.

Shyn et al. ${ }^{(4)}$ reported two other cases of SSAC : a 25 yearold patient with a history of penetrating eye injury for 12 years, and a 21 year-old patient with longtime cataract. In both the cholesterol crystals were confirmed by aspiration in the aqueous humor. Yu et al. ${ }^{(5)}$ describe the case of a 16 year-old patient with SSAC in high myopic eye with no history of ocular trauma, retinal detachment, or intraocular surgery.

Eibschitz-Tsimhoni et al. ${ }^{(6)}$ reported another case of an adult with secondary open angle glaucoma and SSAC associated to Coats disease. They also describe that the enucleation may be considered if there is a condition of untreatable pain or risk of contralateral sympathetic ophthalmia. Gurwood ${ }^{(7)}$ presents a 43 year-old patient with SSAC associated to trauma, subnormal vision and persistent pain. Park et al. ${ }^{(8)}$ describe a 36 year-old patient with SSAC associated to secondary glaucoma and retinal detachment after cataract surgery.

In Brazil, Fortes Filho et al. ${ }^{(1)}$ reported in 2004 the occurrence of SSAC in 5 adults, drawing attention to the onset of this disease in previously traumatized eyes or in the presence of long term cataract.
The occurrence of vitreous colesterolosis is much more frequently found both in daily clinical practice and publications in the scientific literature. In most of the cases reported, the presence of SSAC is related to long term cataract or a degenerative traumatic process of the crystalline, secondary glaucoma or retinal detachment, and its origin is in the crystalline itself or in the vitreous. Until now, there was no description in the literature of SSAC in infant patients, stressing the importance of this case report to the scientific community.

\section{RefERENCES}

1. Fortes Filho JB, Leite Filho WO, Prietsch JF. Colesterolosis bulbi ou sínquise cintilante na câmara anterior: relato de cinco casos e revisão bibliográfica. Rev Bras Oftalmol. 2004;63(5/6):358-63.

2. Gruber E. Crystals in the anterior chamber. Am J Ophthalmol. 1955;40(6):817-27.

3. Andrews JS, Lynn C, Scobey JW, Elliott JH. Cholesterosis bulbi. Case report with modern chemical identification of the ubiquitous crystals. Br J Ophthalmol. 1973;57(11):838-44.

4. Shyn KW, Koo JY, Lee YH. Two cases of cholesterosis bulbi. J Korean Ophthalmol Soc. 1986;27:99-103.

5. Yu YS, Kwak HW, Youn DH. Cholesterol crystals in the anterior chamber. J Korean Ophthalmol Soc. 1980;21:117-9.

6. Eibschitz-Tsimhoni M, Johnson MW, Johnson TM, Moroi SE. Coats' syndrome as a cause of secondary open-angle glaucoma. Ophthalmic Surg Lasers Imaging. 2003;34(4):312-4.

7. Gurwood AS. Diagnostic Quiz. Rev Optom. 2008; 145(5).Available from: http://www.revoptom.com/content/d/diagnostic_quiz/i/810/c/ $15165 /$

8. Park J, Lee H, Kim YK, Chae JD, Lee HJ. A case of cholesterosis bulbi with secondary glaucoma treated by vitrectomy and intravitreal bevacizumab. Korean J Ophthalmol. 2011;25(5):362-5. 